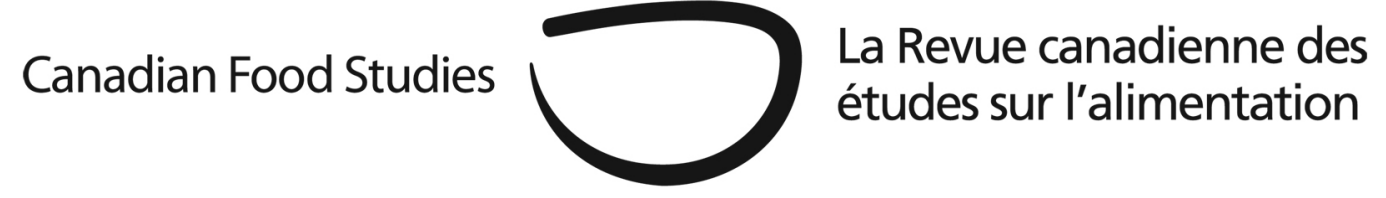

Section III

Global Food Trade

Special Issue: Mapping the Global Food Landscape

\title{
The uneasy relationship between international trade and agriculture - Synthesis paper
}

Kimberly Burnett ${ }^{1}$

PhD Candidate, Balsillie School of International Affairs, University of Waterloo

In his 2006 book, Food is Different, Peter Rosset posited we "get agriculture out of the [World Trade Organization] WTO”. This contention, which is the rallying cry for the Food Sovereignty movement, is that the WTO should not have any purview over agriculture and by extension food systems. Getting the WTO out of agriculture encompasses not only dismantling the 1994 Agreement on Agriculture, which governs both global food trade and extends to national food policies, but also nullifying the entire suite of WTO agreements that apply to various aspects of agriculture, including the Agreement on Trade-Related Intellectual Property Rights (TRIPS), and the Agreement on Trade-Related Investment Measures (TRIMS) (see Burnett \& Murphy, 2014). For activists, policymakers, and scholars who take a firm stance of resistance to the WTO, there is no room for compromise with the institution. From this standpoint, the WTO cannot be transformed into a legitimate space to govern international food trade. The underlying concerns motivating much global civil society resistance to agriculture being governed under the WTO are well documented in the papers in this collection and were discussed at length by participants at the workshop in Waterloo. Indeed, the workshop reflected the wider debates in contemporary global food politics that make the WTO such a polarizing issue; you are either against or for it.

The papers by Murphy, Kripke, and Margulis offer different critical perspectives on trade liberalization's negative consequences, yet even for them (and many others), the WTO's role in

\footnotetext{
${ }^{1}$ The author is grateful for the support from the Canadian Social Sciences and Humanities Council for a JosephArmand Bombardier CGS Doctoral Scholarship \#767-2008-1014 and Balsillie Fellowships through the Centre for International Governance Innovation.
} 
regulating agriculture and food is not so black and white. In this summary, I reflect on the papers and discussions that took place at the Workshop. The WTO, including both specific international trade agreements and its decision-making processes, are undisputed here as seriously flawed. However, the three articles identify opportunities for transforming the WTO to achieve specific ends, such as preventing breakdown in international food trade that disproportionately and negatively affects the citizens of low-income food deficit developing countries (Murphy) or rolling-back the expansion of national agrofuel mandates (Margulis). The discussions at the workshop raised looming questions about the WTO and its future: Can the WTO be reformed to create fairer rules for agricultural production and trade? Can the empowerment of developing and least developed countries (LDCs) create a balancing force against the traditional powers in the WTO, such as the United States and the European Union? Can a shift in global power relations, but also political discourse around food, foster new norms in the multilateral trading system that respect food security and sustainable livelihoods beyond current assertions about the benefits of free trade that are based on abstract economic theories?

\section{WTO out of agriculture}

As Rosset (2006) points out, food is different from other internationally traded goods. Food is the foundation of human survival. It is a human right. Food and agriculture are the backbones of the livelihoods of roughly three billion of the world's people. It is not a commodity and should not be treated on par with commodities such as automobile parts and computer software. From this view that food is different, it is argued by many that we need the "WTO out of agriculture" because the WTO agreements applied to agriculture restrict the ability of governments to support progressive food and agriculture policies for food security and livelihoods, as well as the power and sovereignty of producers and indigenous communities who produce our food.

\section{An undemocratic power bloc}

Another common criticism leveled against the WTO is that it is fundamentally undemocratic and that power is concentrated among a few, which precludes a true representational voice for all its member states. The discussant at the Waterloo workshop noted that " $\mathrm{t}$ ]he WTO reflects the demands of the global North, and cannot change course, even at the risk of its own snuffing out" and that unless the interests of smaller or poorer developing countries had equal weight to the interests of the set of large Western countries, the WTO will be unable to address the problems of the global South. The deadlock of the WTO Doha Round of negotiations and its inability to forge a new deal was seen as example of entrenched power politics of the WTO, which bypasses the interests of poorer countries (Clapp \& Wilkinson, 2010). 
Concerns over the undemocratic nature of the WTO are widespread among supporters and detractors (ActionAid, 2003; Steger, 2009; Wilkinson, 2014). Traditionally, the U.S., EU, Canada and Japan (known as the Quad) had a disproportionate amount of power in the GATT Uruguay Round (1986-1994) trade negotiations that created the WTO. Many report that there were accounts of “arm twisting” in the Uruguay Round, with some developing countries fearing development aid flows and trade preferences threatened, in particular, by the U.S. and EU if they did not sign on to the AoA and other agreements (ActionAid, 2003; Desmarais, 2007). Former WTO Director Generals Mike Moore and Pascal Lamy have both acknowledged such pressure negotiating tactics (ActionAid 2003). In addition, in order to complete the Uruguay Round, many developing countries gave up years of resistance to intellectual property right rules when they signed on to the TRIPS because they were promised greater market access for their key exports, such as agriculture and textiles (Bronckers, 1999, p. 548; Jawara \& Kwa, 2004).

The persistent lack of public accountability and transparency, in both multilateral trade negotiations and trade dispute settlement, has also been a common criticism of the WTO (Charnovitz, 2004; Woods \& Narlikar, 2001). Decision-making at the WTO has also been criticized for the practice of "green room” negotiations, where key decisions are negotiated among a few select countries. Others have cited the absence of space for global civil society to engage with the WTO, contrasting it against the favoured space granted to the private sector. In comparison, other multilateral institutions have reformed to formally give civil society an equal vote in decision-making processes (Desmarais, 2007; Hopewell, 2013).

One of the key points of contention during the workshop discussion was around whether, given the depth of power asymmetries at the WTO and its undemocratic nature, engagement with the WTO by social movements was desirable. Indeed, a concern raised by Annette Desmarais and others was that engaging the WTO and seeking its reform could result in legitimizing the WTO and its neoliberal objectives at the expense of the pursuit of more equitable alternatives and imagining new possibilities.

\section{WTO power entrenched but not immutable}

But others who contest the legitimacy of current WTO rules argue that the institution is not static, and see opportunities for reform. As Sophia Murphy pointed out during the discussion, "the Doha agenda is not the WTO" and there are many aspects of the international trade system that merit further discussion and analysis that can be helpful in advancing progressive food policies, or at least preventing less progressive ones. While recognizing the disproportionate power still held by the U.S. and EU at the WTO, other participants pointed to a number of changes that demonstrate the mutability of power dynamics within the WTO, and potential shifts in the norms that shaped many of the agreements we have today.

One major shift relates to the changing power dynamics at the WTO with the economic rise of Brazil, China and India (Hopewell, 2014; Hurrell \& Narlikar, 2006). Meanwhile, the 
Group of 33 (G33) developing countries are credited with contributing to stonewalling the Doha negotiations through their entrenched demands for greater flexibility for agricultural policy in order to allow for the prioritization of food security, livelihood security and rural development (Burnett \& Murphy, 2014; Raja, 2014; WTO, 2014). The Agricultural Group of 20 (G20) developing countries $^{2}$ at the WTO has also been influential in agricultural negotiations, albeit with less demanding changes than the G33 (Burnett \& Murphy, 2014; Raja, 2013). Civil society organizations during the late 1990s and early 2000s had a greater focus on lobbying WTO members but remained on the outside and unable to influence the negotiating table (Burnett \& Murphy 2014; Esteve, 2011; Scholte et al., 1998; Williams, 2011).

Meanwhile, the neoliberal norms that underscore the WTO (e.g. free trade, privatization, property rights, etc.) may not be as powerful as they were in the 1990s. As Murphy highlights, the global food crisis, during which international food trade broke down, has undermined confidence among many food importing developing countries that the international trade system can deliver food security. Similarly, even rich countries such as Japan have initiated new policies to increase food self-sufficiency. Indeed, the global food crisis revealed that the international trade system, in generating food import dependence and undermining rural livelihoods, both increases vulnerability to food insecurity and fails to provide supply, access, variety and nutrition (see Murphy, this issue). McMichael (2013) argues that the global land grab can be interpreted as the new security mercantilism with states partially opting out of the WTO food trade regime (see also Akram-Lodhi, this issue). In his article and during the discussion, Margulis also noted that food security has become a major point of friction in the WTO negotiations as over the years food security-related provisions have become more widespread in WTO law. While Margulis acknowledged the increasing purview of the WTO over food security has not been sufficiently debated by WTO members, especially by those states who are the most vulnerable to food insecurity, the G33 and others have begun to press the concept that food security trumps trade liberalization.

\section{A world without a WTO could be worse}

A further point of divergence among the workshop participants, and implied by all three of the authors (Kripke, Margulis and Murphy), is that the world without the WTO is potentially more harmful to food security objectives than a world with it. Whether one likes it or not, the WTO regulates food trade and sets the contours around which domestic public food security policies are shaped. Simply put, ignoring the WTO will not make it go away. And as Sophia Murphy

\footnotetext{
${ }^{2}$ The G20 coalition at the WTO is a group of 20 developing countries that includes Argentina, Bolivia, Plurinational State of, Brazil, Chile, China, Cuba, Ecuador, Egypt, Guatemala, India, Indonesia, Mexico, Nigeria, Pakistan, Paraguay, Peru, Philippines, South Africa, Tanzania, Thailand, Uruguay, Venezuela, Bolivarian Republic, and Zimbabwe. It is in no way related to the G20 group of twenty major economies.

https://www.wto.org/english/tratop_e/dda_e/negotiating_groups_e.htm
} 
commented, ignoring the WTO will only let it continue on unchallenged. Whereas many participants read the collapse of the Doha Round as signaling the death of the WTO, Margulis claims this is an incorrect view, noting that despite the current stalemate in negotiations, the WTO is very much alive and its everyday work of enforcing trade agreements and facilitating dispute settlements continue. Margulis’ paper goes a step further and challenges us to think about whether the WTO is a potential resource to regulate national agrofuel mandates and subsidies. Building on this, he also asked during the workshop discussion, given that there are many rules that allow for agricultural supports, whether we can harness these rules more strategically for agricultural development. Tim Wise, admittedly skeptical of the opportunities to use the WTO as a weapon, does see tremendous value in using it defensively to protect food security.

Further, like many convinced we should not abandon the WTO, the panelists voiced concerns that the WTO, for all its faults, is better than a world with no WTO (Kripke, Margulis, and Murphy). Though it seems counter-intuitive, WTO rules may be less malignant than the requirements under the proliferating bilateral and multilateral trade and investment agreements, which often contain deeper neoliberal qualities and have been labelled as "globalization plus" (Wade, 2003). Many of these agreements prohibit import and export restrictions on food and decrease the scope for states to use public health and safety interests to regulate trade. This could increase the vulnerability of developing country agricultural sectors in global markets (GRAIN, 2008). At the WTO, developing countries have been able to use coalitions to negotiate better terms, advance their interests and resist conditions unfavourable to their interests, including food security. Bilateral and plurilateral agreements will not afford them such agency.

The point is not to accept the WTO and its agreements as they are. It is rather to say that the WTO has shown potential for developing countries to resist and exact agency to achieve more favourable trade rules, while a world without the WTO might, instead, result in a trade regime in which developing countries would have less power and face a shrunken policy space.

\section{Imagining beyond the present}

But can the WTO, the UN, or any alternative international or global forum really generate a more equitable trading system that will give priority to food security? Or, as one panel discussant put it: will the U.S. remain "the guerilla in the world that sits wherever it wants", ultimately determining the direction of trade rules wherever it sits? This is an open and unresolved question. Hopewell (2013; 2014) argues that Brazil and India really only have power in WTO negotiations where they are bolstering neoliberal trade practices and are not necessarily system challengers. In his paper, Kripke argues U.S. opposition to the India Right to Food program is a demonstration of it playing what is essentially the role of the guerilla at the WTO. Yet, despite the power of the U.S., the WTO negotiations have stalled because of the demands of developing countries for greater policy space, in particular for food security (Burnett and Murphy, 2014; Margulis, 2014). And not only is power shifting, but so too have the contours and dynamics of the global food 
system, and as Murphy suggests, there is a case to be made for international trade rules to regulate agriculture in the present and future but these will need to be dramatically different from what is currently in place at the WTO. The divide among participants at the workshop was largely around strategies to enable an alternative global food system, some seeing it necessary to euthanize the WTO to make room for a new path, others imagining a way to seize opportunities, however limited, within the problematic institution to build a new international trade regime that is truly democratic and committed to ending poverty, ensuring food security and the human right to food, and to doing so sustainably.

\section{References}

ActionAid. (2003). WTO democracy and reform. London: ActionAidUK. Retrieved from http://www.actionaid.org.uk/sites/default/files/doc_lib/54_1_wto_democracy_refor $\underline{\text { m.pdf }}$

Bronckers, M.C.E.J. (1999). Better rules for a new millennium: A warning against undemocratic developments in the WTO. Journal of International Economic Law, 2(4), 547-566.

Burnett K., \& Murphy, S. (2014). What place for international trade in food sovereignty? Journal of Peasant Studies, 41(6), 1065-1084.

Charnovitz, S. (2004). The WTO and cosmopolitics. Journal of International Economic Law, 7(3), 675-682.

Clapp, J., \& Wilkinson, R. (2010). Governing poverty and inequality. In J. Clapp \& R.

Wilkinson (Eds.). Global governance, poverty and inequality (pp. 1-23).

Routledge.

Desmarais, A.A. (2007). La Vía Campesina: Globalization and the power of peasants. Halifax: Fernwood.

Esteve, M.P. (2011, May 9). WTO Rules and practices for transparency and engangement with civil society. Working Paper Draft prepared for the IISD-Entwined Workshop. Geneva: IISD. Retrieved from http://www.iisd.org/pdf/2011/wto_accountability_rules_transparency.pdf 
GRAIN. (2008). Food exports and free trade agreements. Retrieved from http://www.grain.org/es/article/entries/179-food-exports-and-free-tradeagreements

Hopewell, K. (2013). New protagonists in global economic governance: Brazilian agribusiness at the WTO. New Political Economy, 18(4), 603-623.

Hopewell, K. (2014). Different paths to power: The rise of Brazil, India and China at the World Trade Organization. Review of International Political Economy, (online first), 1-28.

Hurrell, A., \& Narlikar, A. (2006). A new politics of confrontation? Brazil and India in multilateral trade negotiations. Global Society, 20(4), 415-433.

Jawara, F., \& Kwa, A. (2004). Behind the scenes at the WTO: The real world of international trade negotiations. Zed Books.

Margulis, M. E. (2014). Trading out of the global food crisis? The World Trade Organization and the geopolitics of food security. Geopolitics, 19(2), 322-350.

McMichael, P. (2013). Land grabbing as security mercantilism in international relations. Globalizations, 10(1), 47-64.

Raja, K. (2013). Agri chair reports on consultations on G33, G20 proposals. Third World Network. Retrieved from http://www.twnside.org.sg/title2/twe/2013/550/4.htm

Raja, K. (2014). G33 Ministers stress importance of food security. Third World Network. Retrieved from http://www.twnside.org.sg/title2/resurgence/2014/281282/cover06.htm

Rosset, P. (1996). Food is different: Why we must get the WTO out of agriculture. London: Zed.

Scholte, J.A., O’Brien, R., \& Williams, M. (1998). The WTO and civil society (CSGR Working Paper No. 14/98). Warwick, UK: Centre for the Study of Globalisation and Regionalisation,. University of Warwick, Coventry.

Steger, D. P. (Ed.). (2009). Redesigning the World Trade Organization for the twenty-first century. Waterloo, ON: Wilfrid Laurier University Press. 
Wade, R.H. (2003). What strategies are viable for developing countries today? The WTO and the shrinking of development space. Review of International Political Economy, 10(4), 621-44.

Wilkinson, R. (2014). What's wrong with the WTO and how to fix it. John Wiley \& Sons.

Williams, M. (2011). Civil society and the WTO: Contesting accountability. In J.A. Scholte (Ed.) Building global democracy? Civil society and accountable global governance (pp. 105-127). Cambridge, UK: Cambridge University Press.

Woods, N., \& Narlikar, A. (2001). Governance and the limits of accountability: The WTO, the IMF, and the World Bank. International Social Science Journal, 53(170), 569-583.

WTO. (2014). Groups in the negotiations. Retrieved from http://www.wto.org/english/tratop_e/dda_e/negotiating_groups_e.htm 